\title{
Facilitating Innovation in the Economy of Choice: A Case Study of Research on Museum
}

\author{
${ }^{1}$ Duan Wu, ${ }^{2}$ Chenxi Yao, ${ }^{3}$ Jiping Wang \\ ${ }^{1,2}$ College of Design and Innovation, Tongji University, Shanghai, China \\ ${ }^{3}$ School of Art Design and Media, East China University of Science and Technology, Shanghai,
}

China

\begin{abstract}
Over the past decade, museums all over the world have faced increasing pressures to transform as a result of visitor changes and technological advancement. "Excellence and Equity: Education and Public Dimension of Museums" published by the American Association of Museums (AAM) describe that the museum has become an intermediary and public education centers for social inclusion (Yuha Jung, 2011). In the economy of choice, it is no longer collections that drive the priorities of museums but rather the needs of communities. At the same time, museums increasingly rely on the interpretation of their resources to provide distinctive experiences that attract and engage visitors. New challenges lead to new applications. With this background, innovation, which in essence can be defined as "the development of new customer's value through solutions that meet new needs, inarticulate needs, or old customer and market" (Alshammari, A. A., Rasli, A., Alnajem, M., \& Arshad, A. $S, 2014$ ) has become a key factor for the success of museum.
\end{abstract}

Through case studies and analysis with multiple design methods in open innovation and social innovation, this research seeks to better understand the role of "innovation" in the interpretation projects in a modern museum perspective, and the role of strategic design in the transforming complicated context of modern museum to help reach out the most practical strategy. Moreover, the paper presents a new framework for innovation methods to be used in the modern museum context. The theoretical framework is based on three concepts: open innovation, social innovation and innovative design thinking toolkit. The framework is structured to make innovation in the museum more replicable, scalable and operable, and it could be used as a planning tool to carry out innovation or evaluate innovation.

This paper argues that museum innovation is a field of specialized interdisciplinary practice that exemplifies the highly collaborative and strategic nature of contemporary design practice. Designer's role in this transforming context should be the leader, the facilitator, the generalist, the user advocate and the analyst. This article is still at an early step in the challenges of museum innovation and the research will continue.

Keywords: Museum, Innovation framework, Design thinking, Toolkit, Economy of choice

\section{Museum Innovation in The Economy of Choice}

The museum is "collection centered" previously. It is like a warehouse with lots of historical and artistic collection. The development of the museum strictly adheres to its industry standards, forming a top-down professional management mode based on professional. (Lin Li, 2015) With this background, the visitors of museums are mostly scholars and celebrities, while marginalized groups are excluded, which makes them unable to participate in activities of 


\section{Duan Wu, Chenxi Yao, Jiping Wang}

Facilitating innovation in the economy of choice: A case study of research on museum

museums. These days, under the impact of economy of experience ${ }^{1} 2$, the cultural and entertainment industry is becoming increasingly competitive, and traditional public institutions such as museums have to reposition and change their minds. The journalist Henneth Hudson concludes in the international museum magazine: "over the past half-century, the most fundamental change to the museum is... a universal belief in serving the public." (Hudson, $\mathrm{K}$, 2014) The management of the museum needs to adapt to the new market competition environment and put the needs of the public in a prominent position. (Kotler, Kotler, N. G. /., Kotler, P. /., \& Wendy, I, 2018)

1. Traditional management model based on industry standard

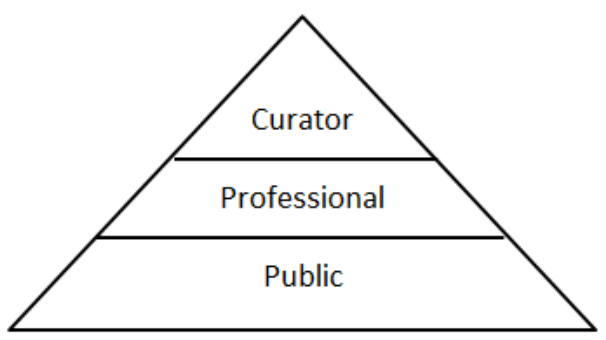

2. Experience management model based on public needs

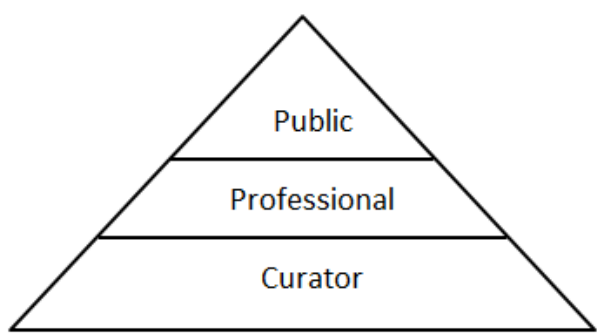

Figure 1: Comparison diagram of museum management mode

We divide the arenas of the daily life of the public into play, learn, home, work, and health. Different arenas contain different needs. It illustrates from Figure 2 that Information technology has continuously pulled in the five arenas' distances which means the public's needs have become more convergent. This puts forward higher requirements for the development of museums in the economy of experience and economy of choice.

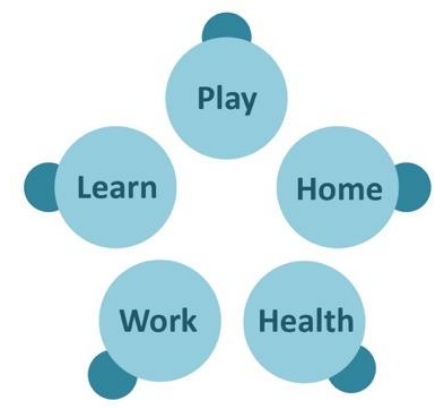

Independent arenas supported by specialized technology. E.g.:TV was for play, computers for work.

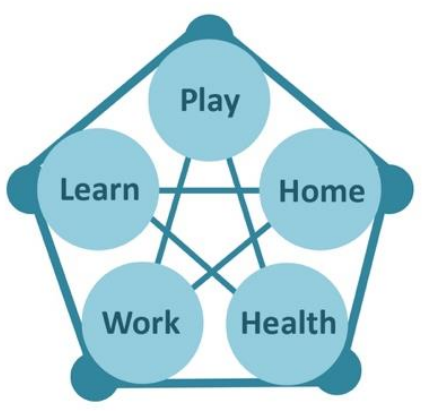

Connected arenas supported by communication networks.

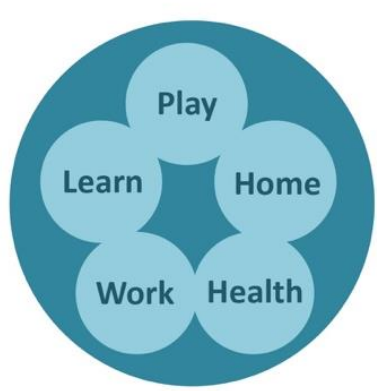

Integrated arenas use same information infrastructure.

Figure 2: Interrelation of the arenas of daily life

\footnotetext{
1 The term "Experience Economy" was first used in a 1998 article by B. Joseph Pine II and James H. Gilmore, describing the experience economy as the next economy following the agrarian economy, the industrial economy, and the most recent service economy. Pine and Gilmore argue that businesses must orchestrate memorable events for their customers, and that memory itself becomes the product: the "experience". More advanced experience businesses can begin charging for the value of the "transformation" that experience offers.

2 Moreover, the economy of choice driven by flexible production and new business frameworks. Consumers have more options for everything - how they live, how they work, how they learn, and how they play.
} 


\section{Duan Wu, Chenxi Yao, Jiping Wang \\ Facilitating innovation in the economy of choice: A case study of research on museum}

In addition to information and products beginning to react and be complicated, consumers and users were faced with an unprecedented number of choices in the economy of choice. Together, these changes caused an underlying power shift from individual producers to consumers. It became vital for organizations to understand people's needs and aspirations. (Whitney, P, 2015) Many studies have shown that lots of people interested in, and even social activities, is not only confined to read labels and watch collections. (Liuhe Zheng,\& Peng Liu, 2013) We summarize the new trends of the museum visitors' needs as follows:

- More visitors are looking for engaging and participatory museum activities. Sozanski reports that many art museums have added some facilities and activities that are not directly related to art. For example, The James A. Michener Art Museum recently built a new pavilion "art-free" for concerts, lectures and receptions. The Philadelphia Museum of Art launches the "Jazz Fridays" series and the Museum of Modern Art offers yoga classes. These events show that the museum is trying to attract new arrivals. Although they are not regular visitors to the museum and not have particular interests in art, they are pleased to spend time with friends or family in a community-based environment. (Liuhe Zheng,\& Peng Liu, 2013)

- The visitors to museums not only content to appreciate the collections but also want to interact with museums and other communities. Many people regard the museum as a social place where people can feel the love and participate in it, exchange their ideas and promote the generation of knowledge. The museum is no longer a place for transmitting authoritative knowledge. Ann Philbin, director of the hammer museum at the University of California, Los Angeles, said the museums are not just institutions for art and history, but a "new community centers." (Liuhe Zheng,\& Peng Liu, 2013)

- With the development of social networking, museum visitors are keen to take photos of the exhibits and share their experiences and feelings on social platforms. Also, more and more people use the information on social media as a reference for various decisions. For the museum, social media has become a new element to the museum's communication, providing the possibility of more interactive communication between the museum and the audience.

The business philosophy of the museum gradually became "visitors centered". According to the visitors' needs, the future development trend of the museum can be summarized as a participatory museum, community-based museum, and shared museum. These trends have brought significant challenges to museums. In order to meet the needs of future visitors and the trends of the future museum, museums need to be constantly innovative. New challenge leads to new applications. With this context, an innovation which in essence can be defined as "the development of new customer's value through solutions that meet new needs, inarticulate needs, or old customer and market" (Eid, Haitham Abdelrazek, 2016) has become a key factor for the success of the museum.

\section{A Museum Innovation Framework Based on Design Thinking}

In the economy of choice, the strategic capabilities of design are of much greater importance. Eventually, new frameworks emerge to explain how users, businesses, platform and technology adapt. Design thinking, which considering holistic systems, recognizing the intangible value, and reframing problems will provide more general and broader ways to face the challenging and create value. 


\section{Duan Wu, Chenxi Yao, Jiping Wang}

Facilitating innovation in the economy of choice: A case study of research on museum

In Prof. Patrick Whitney's "the whole view" design thinking framework, he shows eight core capabilities of design, including abstraction, reframes, imagines new options, visualize ideas, empathy, probabilistic systems, and operations. The framework also indicates the relationships to the fundamental questions of design and to a more comprehensive set of concerns that are vital to innovation. (Whitney, P, 2015)

Triggered by "the whole view" framework, in this paper, we outline a four-part framework for the use of museum innovation, which start with the four key questions: WHAT, WHO, WHY, and HOW. When problems that involve new users, new trends, a new process or new frameworks, direct solutions are always far from the best approach. This requires the thinking in holistic systems and the reframing of the very basic key questions. With the context of the museum, among the many methods and frameworks related with design thinking and innovation, we chose four methods and frameworks according to the key questions that enable fast, informal sketches when reframing the system with a whole and innovative view, and also capable of achieving innovation in a complex context. In this paper, we will choose some of the methods that we used in the research and case studies to explain.

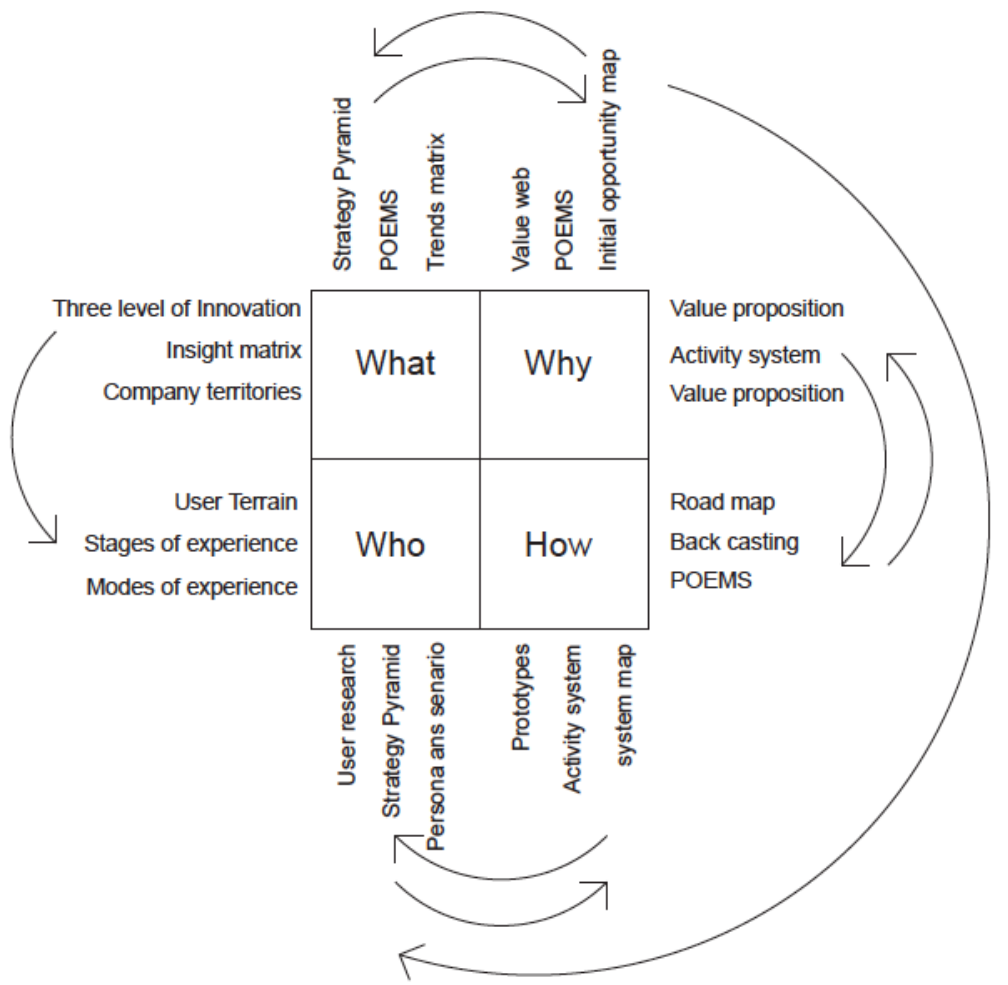

Figure 3: Museum innovation framework

\subsection{Activity Systems}

Professor Michael Porter of Harvard creates the activity system framework. It can be used to show how a company's strategic position is contained in a set of tailored activities designed to deliver it by showing the critical activities needed to bring innovation to life and the interdependencies among them. It also can be useful for examining and strengthening the strategic fit. In companies with a clear strategic position, several higher-order strategic themes can be identified and implemented through clusters of tightly linked activities. (Porter, M. E, 1996) Taking these interdependencies into account while the project is still at an early phase allows companies to ascertain where an important activity lacks a necessary prerequisite activity. Without this early view, it is likely that companies will not discover missing capabilities until after the innovation is launched. (Whitney, P, 2015) 


\section{Duan Wu, Chenxi Yao, Jiping Wang}

Facilitating innovation in the economy of choice: A case study of research on museum

Activity system will help the innovation process in the following ways:

- Make incremental decisions about whether a new idea or opportunity fits the strategy.

- Communicate how every function and policy contributes to the organization strategy.

- Identify mis-fit activities.

- Decide the boundary of the organization.

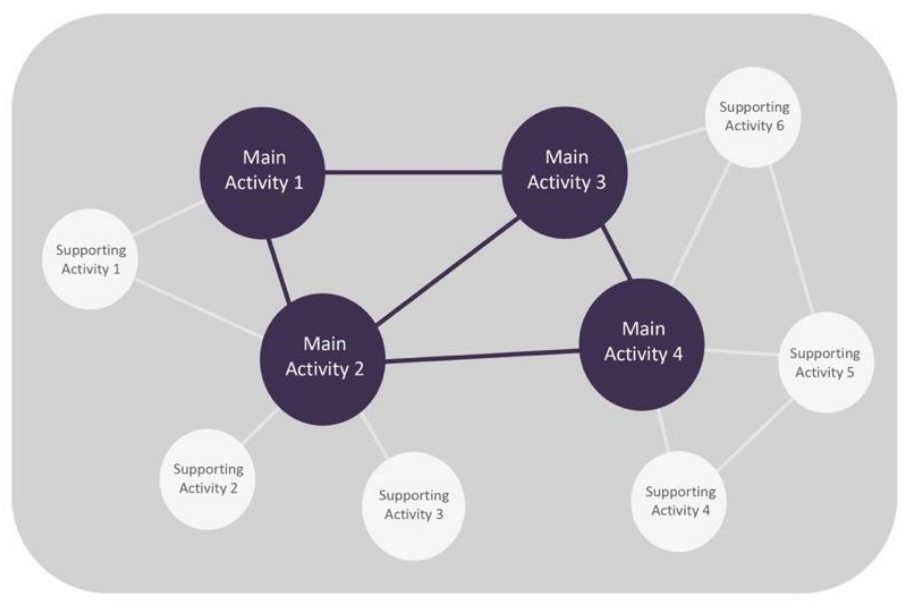

Figure 4: Activity Systems

\subsection{User Terrains}

Terrains are different from the market segments. Market segments are the classification of people based on demographic factors and their propensity to buy what a company offers. While people's aspirations and needs identify terrains. Aspirations include having a happy and inviting home; succeeding at a sport or hobby; providing enriching life experiences for one's children; and achieving high social status. Needs are the high-level goals people have for themselves and those close to them. These can be identified by how people spend their time, attention, and money.

This framework can help companies to focus on their goals by establishing territories inside existing terrains, or carving out new territories between terrains. Moreover, it also can help companies avoid myopically positioning people in the context of the company rather than in their social context by separating terrains and territories. While this may not have been important when people had few choices, it is essential now. (Whitney, P, 2015)

It is a tool that was reducing risk, raising resilience, deploying data. Designing resilience into supply chains and value webs will likely rise in importance, and be supported by new capabilities.

- helps look at each aspect of the uncovering potential value and spurring creativity.

- helps create competitive barriers because the interwoven parts are more difficult to copy.

- highlights the potential opportunities to revive.

- create an atmosphere of continuous improvement. 


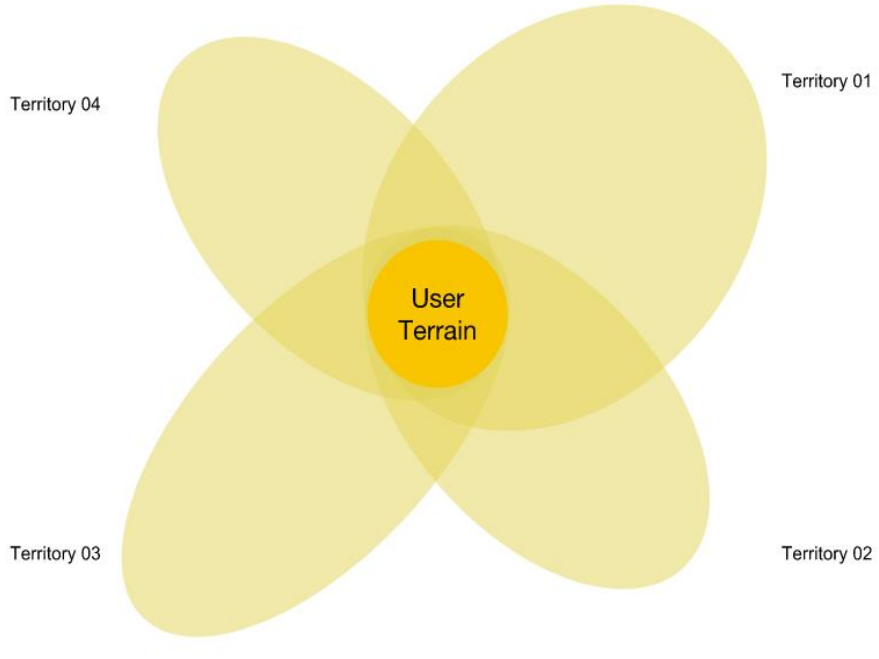

Figure 5: User Terrains

The above methods or frameworks are interconnected and can present a formula in museum innovation. They could be used separately or together according to different museum background and innovation sectors. The objective of the framework is to help innovation in museums generating more scalable, replicable and feasible.

It is difficult to see the benefits of new frameworks or frameworks until they have been tried and tested. Therefore, we choose the Art Institute of Chicago as a case study to test the framework and follows a trial of the framework in the innovation research of Shanghai Museum of Glass.

\section{The Case Study of Art Institute of Chicago}

"Innovative pioneers", represented by Art Institute of Chicago, have made bold innovations to meet new market conditions. Art Institute of Chicago was named the world's best museum by TripAdvisor, and it is a must-see for any trip to Chicago.

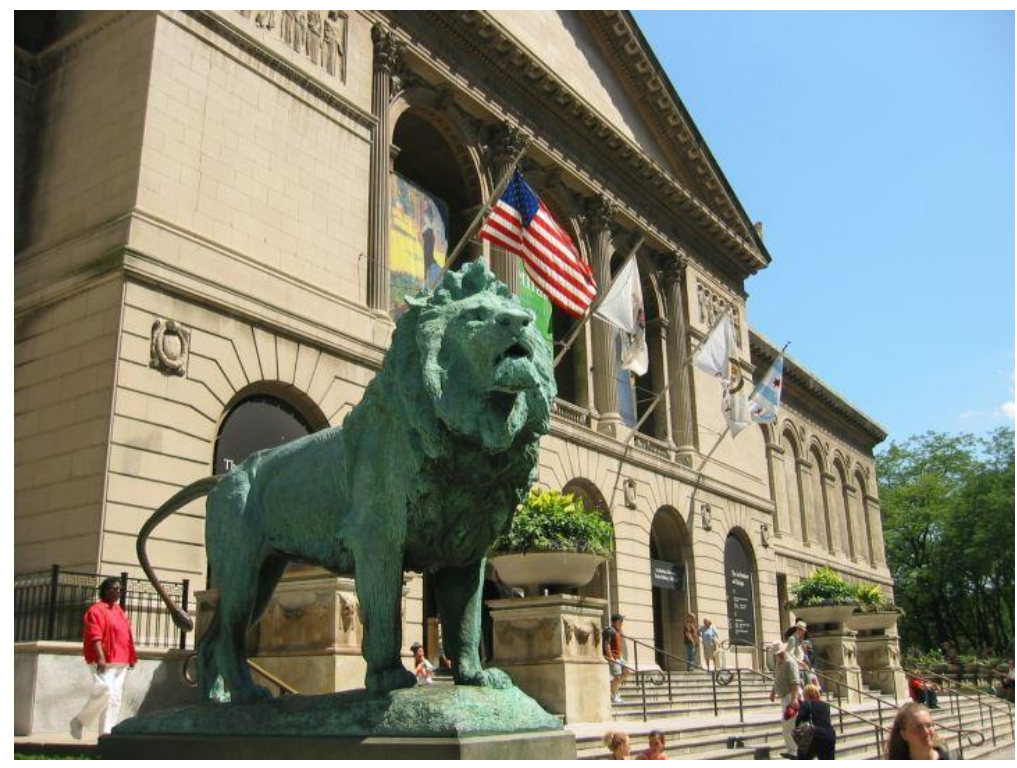

Figure 6: Art Institute of Chicago 


\section{Duan Wu, Chenxi Yao, Jiping Wang}

Facilitating innovation in the economy of choice: A case study of research on museum

The Art Institute of Chicago is one of the oldest and largest art museums in the United States, founded in 1879 and located in Chicago's Grant Park. Recognized for its curatorial efforts and popularity among visitors, the museum hosts approximately 1.5 million guests annually. Its permanent collection of nearly 300,000 works of art, which stewarded by 11 curatorial departments, is encyclopedic. (Wikipedia)

In recent years, the Chicago Academy of art has made many attempts in the field of innovation. We use User Terrain and Activity-system map to analyze the innovative framework of the Art Institute of Chicago.

According to the aspirations and needs of visitors from the Art Institute of Chicago, we can divide them into four categories: visitors who want to learn knowledge about art, get information on art research, enjoy their time in the art space and have social interaction in the museum. According to the overlapping of the four terrains, we can realize that the Art Institute of Chicago's position is a participatory museum. (Figure 7) On this basis, we use the Activitysystem map to illustrate the innovation framework of the Art Institute of Chicago.

Mapping User Terrains of Art Institute of Chicago

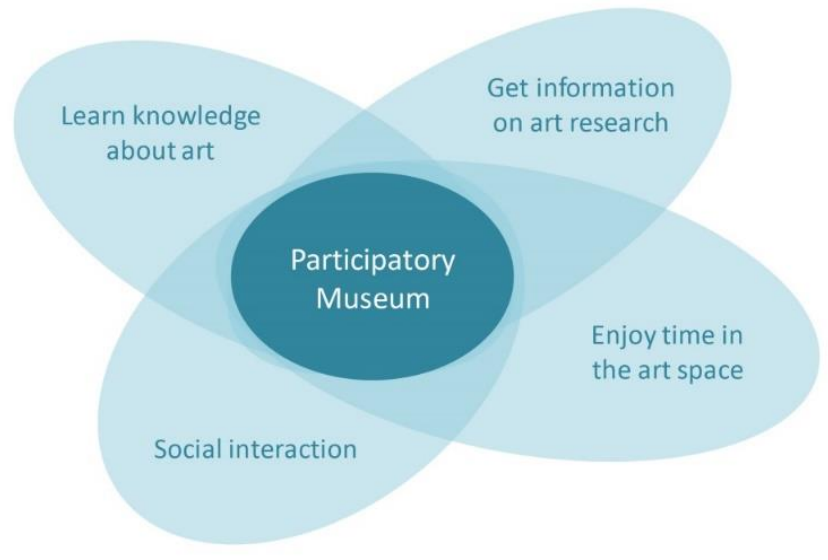

Figure 7: Mapping User Terrain of The Art Institute of Chicago

Activity-system map is one of the innovative tools. We can use a set of basic questions to guide the process. First, is each activity consistent with the overall positioning - the varieties produced, the needs served, and the type of customers accessed? Second, are there ways to strengthen how activities and groups of activities reinforce one another? Finally, could changes in one activity eliminate the need to perform others? (Porter, M. E, 1996)

Then we mapped the activity system of the Art Institute of Chicago by the process. As shown in Figure 10, the innovation of The Art Institute of Chicago mainly comes from providing a series of participatory experience, which is divided into four aspects as follows. 


\section{Duan Wu, Chenxi Yao, Jiping Wang}

Facilitating innovation in the economy of choice: A case study of research on museum

\section{Mapping Activity Systems of Art Institute of Chicago}

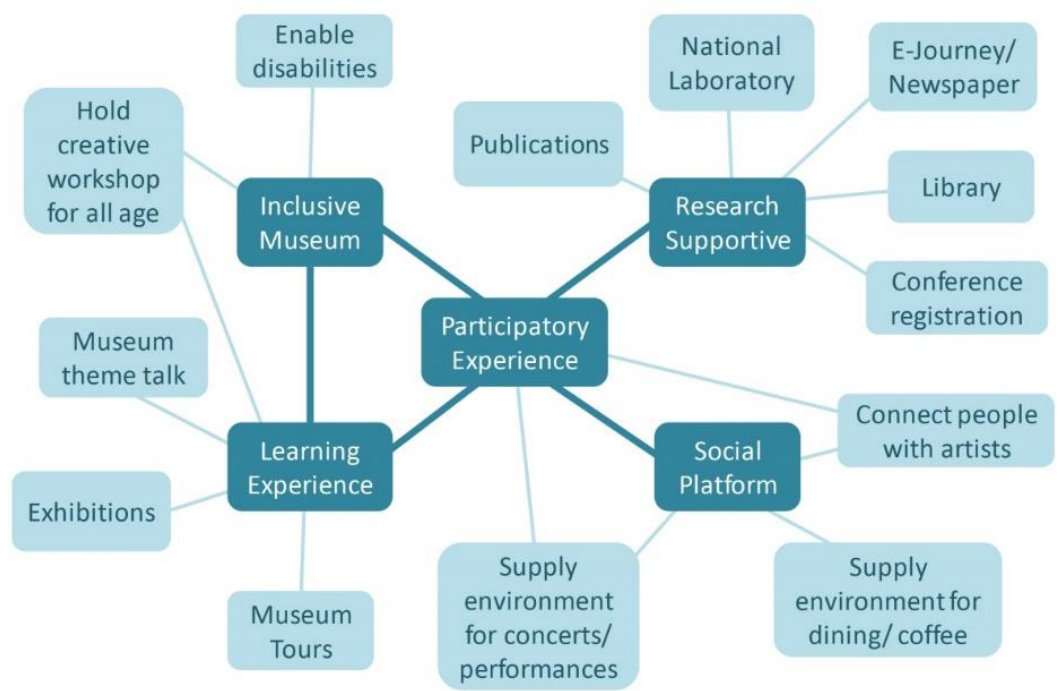

Figure 8: Mapping Activity System of The Art Institute of Chicago

\subsection{Learning experience}

The Art Institute of Chicago has nearly 300,000 permanent collections, and it is augmented by more than 30 special exhibitions mounted yearly to present cutting-edge curatorial and scientific research. (Wikipedia) These exhibitions give visitors a good experience of appreciation and learning. In addition, the museum also provides Museum Tours suitable for all age, such as Block Party, Students Tours, Teach Tours, Teens Tours, Families Tours, Adults Tours, Journey-Maker Tours, Multimedia Finders Tours etc. (Art Institute of Chicago official website) In this tour, visitors can interact closely with art and art media, and can also participate in performances, speeches, storytelling and art making. Docent-led museum tours emphasize close looking, discussion, and critical and creative thinking by making connections with works of art.

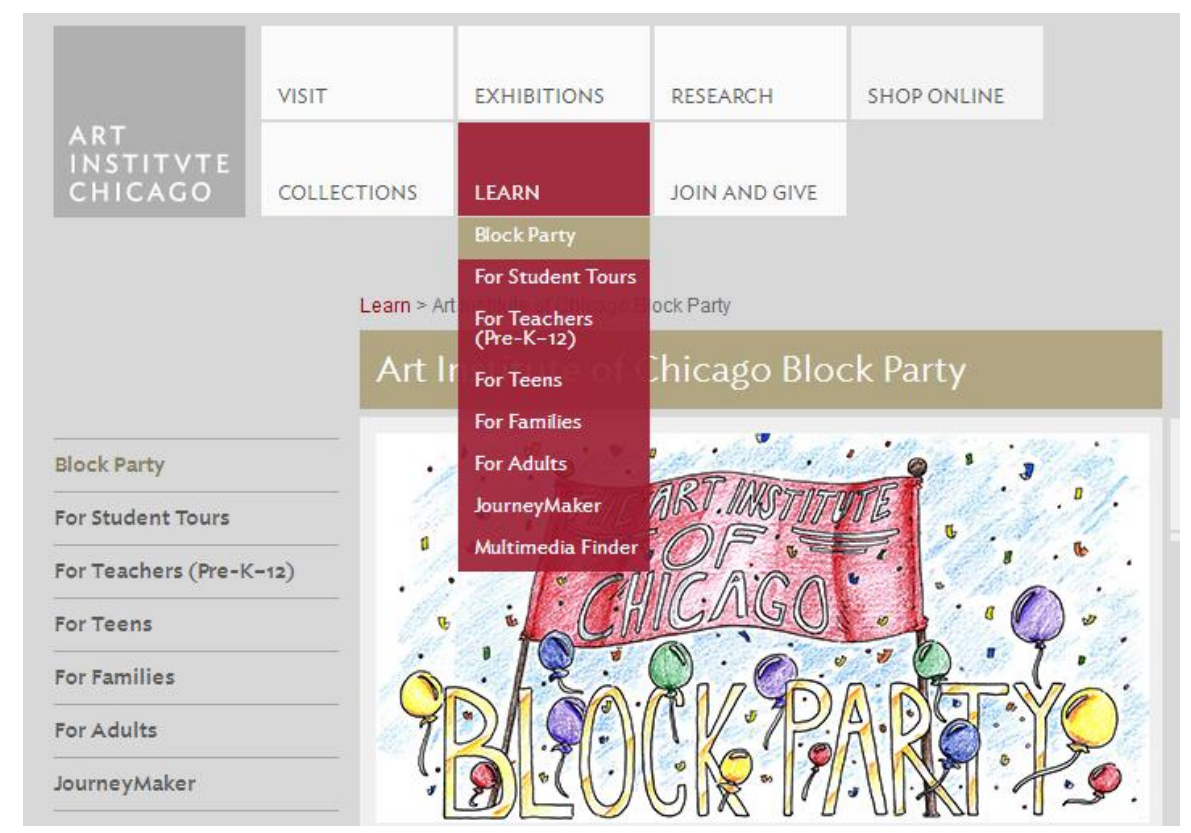

Figure 9: Learning activities of the Art Institute of Chicago 


\section{Duan Wu, Chenxi Yao, Jiping Wang}

Facilitating innovation in the economy of choice: A case study of research on museum

\subsection{Research supportive}

Research is at the heart of every activity at the Art Institute of Chicago: building and caring for the collection, organizing exhibitions, producing scholarly publications, and presenting new and engaging information to the public. Driven by the museum's eleven curatorial departments in collaboration with the museum's conservation and science departments, the Ryerson and Burnham Libraries, and the department of Publishing, research forms the foundation of the Art Institute's reputation for innovation and scholarship. The department of Academic Engagement and Research was formed in 2017 to advance interdisciplinary, exploratory research on the museum's collections and to support collaborations between professors, students, scholars, artists, and museum staff, including fellowship programs and scholarly initiatives. Partnerships with local institutions, such as the University of Chicago, Northwestern University, and Argonne National Laboratory, create opportunities for new developments in curatorial and conservation research. (Wikipedia) The public can also find e-journey, newspaper and other digital Publications in its online library.

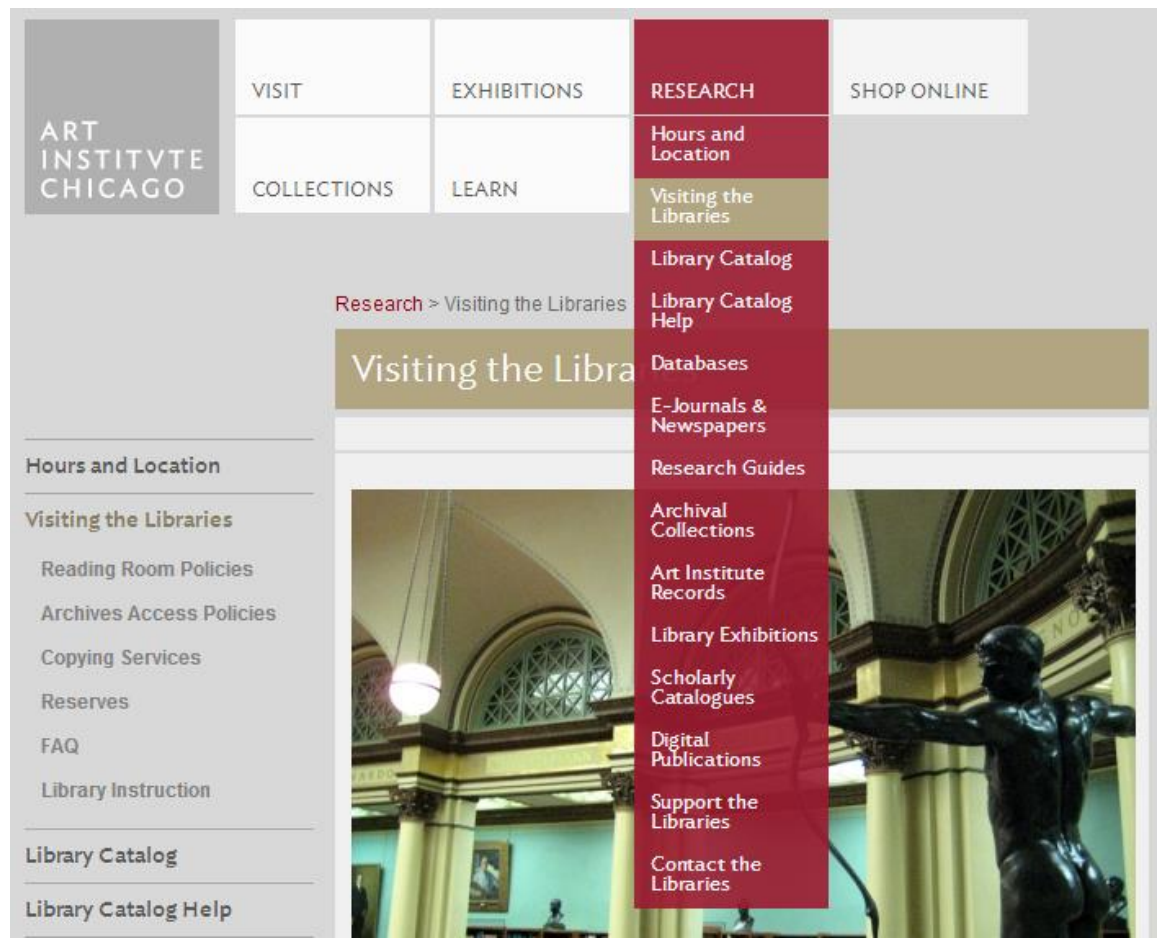

Figure 10: Research activities of the Art Institute of Chicago

\subsection{Inclusive Museum}

The Art Institute of Chicago commits to making its programs and services accessible to everyone. The museum has a range of resources and programs designed specifically for adults and children with disabilities, such as Wheelchair Assistance, Mobility Devices, Hearing-Assist Devices, Sign Language, Tours with Sighted Guides, Touch Gallery. (Wikipedia) Also, it often holds creative workshops for all age. Moreover, if visitors are visiting Chicago for business or pleasure, the museum can help to connect with other museum and the city. 


\section{Duan Wu, Chenxi Yao, Jiping Wang}

Facilitating innovation in the economy of choice: A case study of research on museum

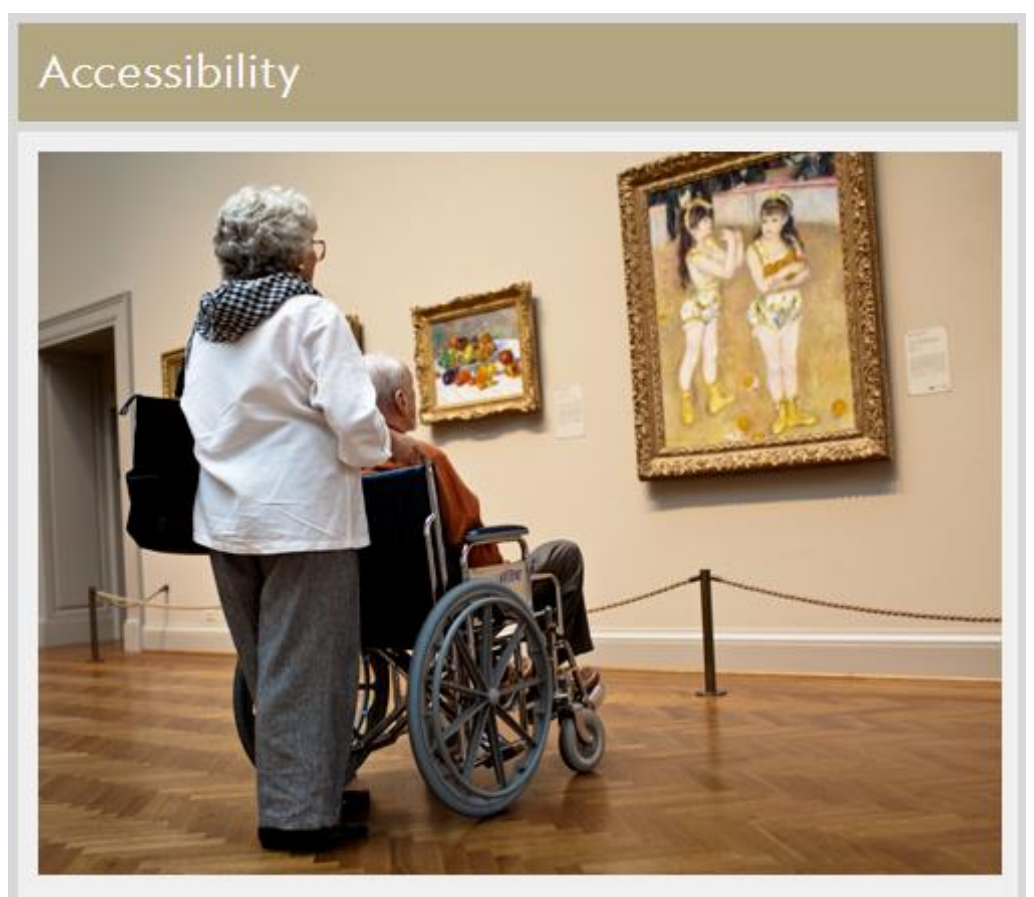

Figure 11: Art Institute of Chicago provides wheelchairs for disabilities

\subsection{Social platform}

The Art Institute of Chicago has developed an official website to connect people with museums, arts, artists and other supporters. The public can search for information, buy tickets, and talk to the community on the official website. Further, it supplies the environment for concerts and performances and dining and coffee for visitors.

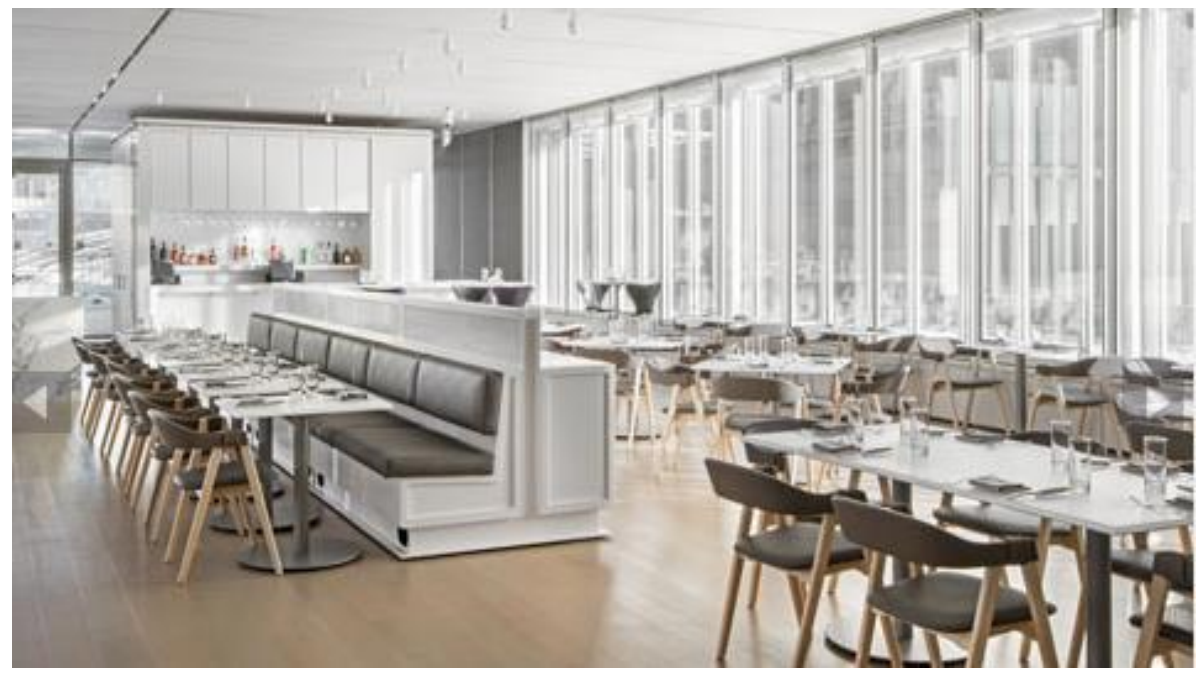

Figure 12: Social environment for dining in the Art Institute of Chicago

User Terrain and Activity-system map can illustrate the innovation framework of The Art Institute of Chicago, which is a useful attempt to use innovative tools in the field of Museology. We can also use them to help other museum mapping innovation and development framework to find new opportunities. 


\section{The Application of the Innovation Framework in Shanghai Museum of Glass}

Shanghai Museum of Glass is the first glass museum in China, located on a former glass manufacturing site in Baoshan District, Shanghai. In October 2012, CNN Go's websites named Shanghai Museum of Glass as one of "China's three must-go museums" and then ranked the museum as one of "Shanghai's five best museums." (Shanghai Museum of Glass official website)

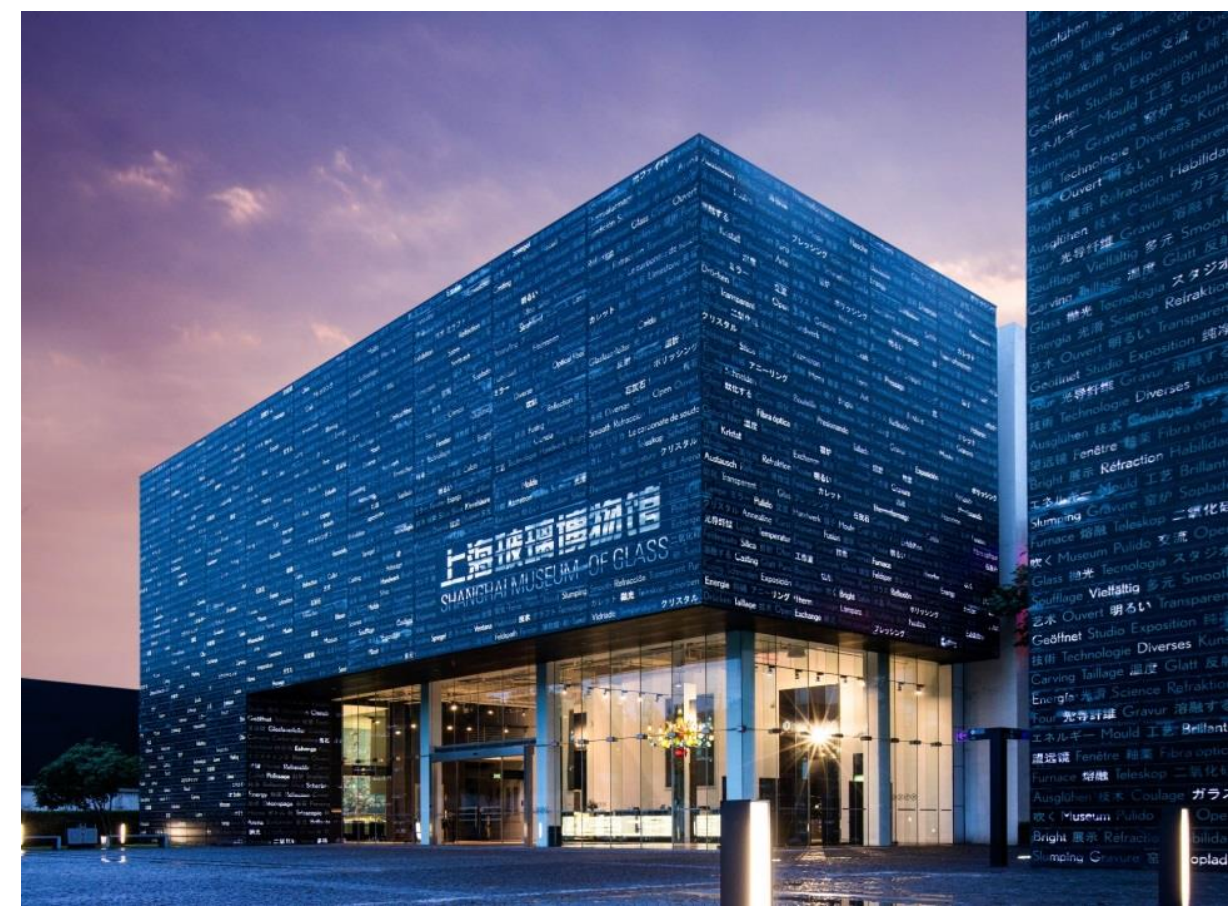

Figure 13: Shanghai Museum of Glass

Since opening its doors in 2011, the Shanghai Museum of Glass has presented a variety of top international exhibitions and events, including yearly ancient glass exhibitions and 'Keep It Glassy', that engages artists and designers from countries such as the USA, UK, Italy, Germany, the Netherlands, Turkey, Australia, Mexico, Kenya, Japan and South Korea. (Shanghai Museum of Glass official website)

It develops from two existing buildings: a former glass bottle factory, and a warehouse. Taking cues from similar industrial parks around the world, the Shanghai Museum of Glass has grown dramatically and forms a museum park: the home to the multi-functional glass themed Shanghai Museum of Glass PARK, with the Shanghai Museum of Glass as its core. The park seeks to express and explore the endless possibilities of glass, the park and the city. (Shanghai Museum of Glass official website)

With the development of the Shanghai Museum of Glass, there are more and more activities.

- The re-frame-worked exhibition hall opened a year-long exhibition "Keep it Glassy."

- A China's only Private membership club set within a museum, KILN Club provides dining and social environment for visitors.

- The museum's Coffee Shop opened to visitors.

- Hot-glass performance is performed in a 60-year-old factory.

- The Kids Museum of Glass opens to the public, and kids and families can interact with glass arts in it. 


\section{Duan Wu, Chenxi Yao, Jiping Wang}

Facilitating innovation in the economy of choice: A case study of research on museum

- Kids Design Glass project gives full play to the creativity and imagination of the children and connects children with artists.

- A wedding ceremony can hold in Rainbow Chapel, and the public can marry in the Museum.

- The DIY Lifestyle which covering a dozen of glassmaking techniques and seven courses provides visitors with the opportunity to experience making glass crafts.

- Visitors can experience in the MAZE which is the only large-scale glass-theme interactive installment in Shanghai.

- Museum Tours makes tourists interact closely with arts and glass.

- Glassy Workshop provides Glass melting experience.

- The museum often holds lectures on different topics.

- "Bobolili Lab" allows children to do glass experiments and learn glass related knowledge.
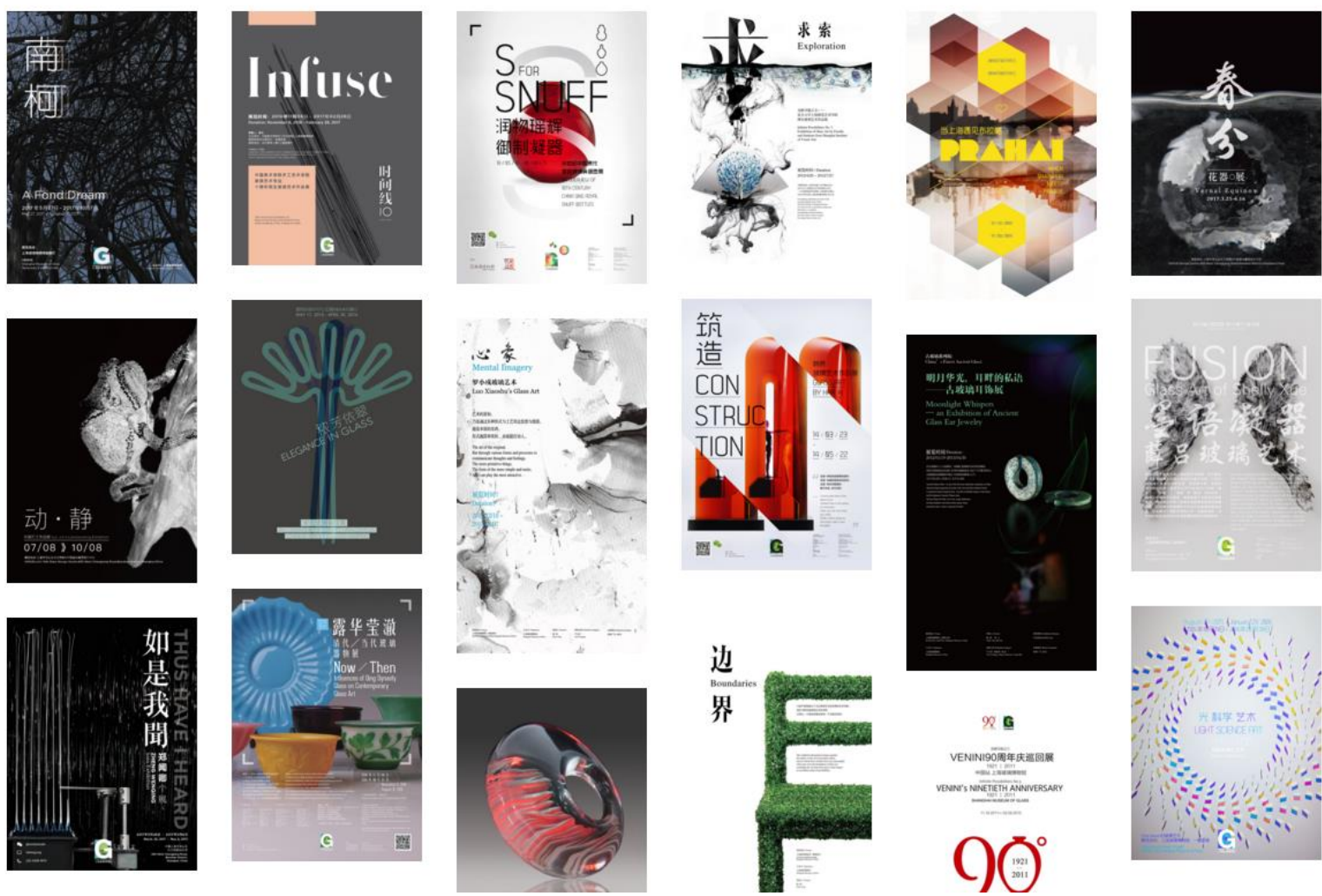

Figure 14: Exhibitions of the Shanghai Museum of Glass

According to the present activities of Shanghai Museum of Glass, we mapped the activities framework of Shanghai Museum of Glass to check the relationship between them and tries to evaluate the "fitness" of the museum activities. (Figure 15). 


\section{Duan Wu, Chenxi Yao, Jiping Wang}

Facilitating innovation in the economy of choice: A case study of research on museum

\section{Mapping Activity Systems of Shanghai Museum of Glass at present}

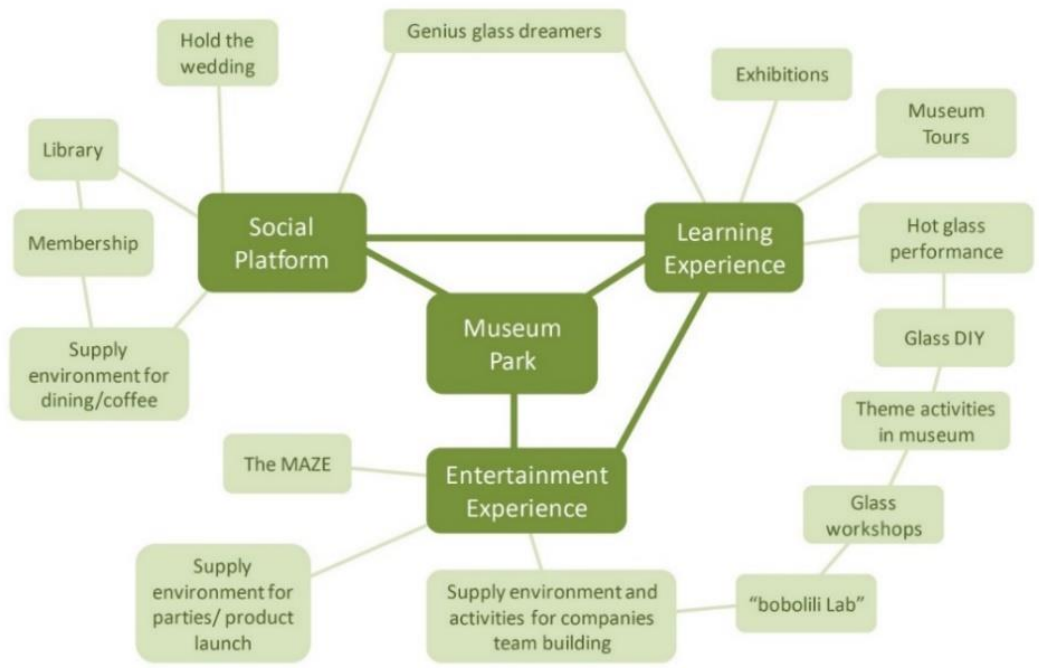

Figure 15: Mapping Activity system of Shanghai Museum of Glass at present

As shown in figure 15, the concept of the Shanghai Museum of Glass is the Museum Park ${ }^{3}$, which is the most distinctive feature that distinguishes it from other museums. The three directions of its development are Community-based Museum and Learning Experience and Entertainment Experience.

We use User Terrahin to map the position of the Shanghai Museum of Glass. (Figure 16) The visitors of the Shanghai Museum of Glass can divide into four parts: people who want to learn knowledge about glass and art, entertain at their leisure time, connect with art and artists and social interaction in the museum. According to the overlap area of four terrains, we can know that the position of Shanghai glass museum is a museum park of art and life.

\section{Mapping User Terrains of Shanghai Museum of Glass}

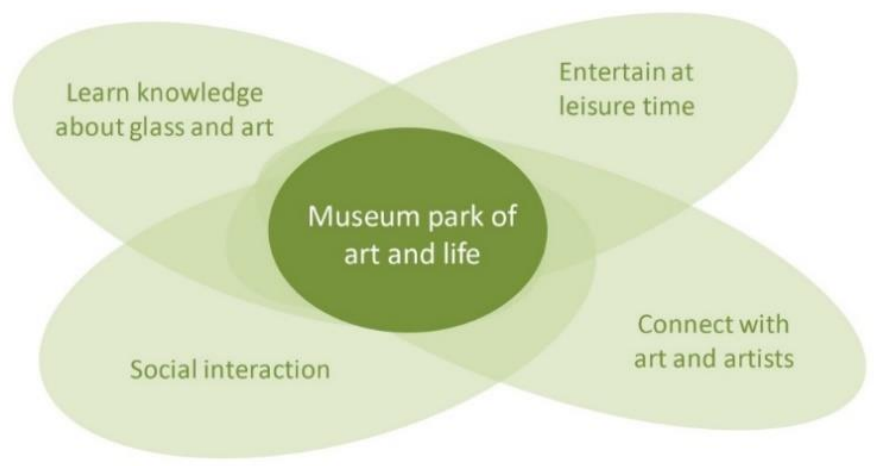

Figure 16: Mapping User Terrains of Shanghai Museum of Glass

3 Under the principle of Creating and Sharing Museum Aesthetic New Life, the Shanghai Museum of Glass founded the brand new and multi-functional Shanghai Museum of Glass Park. Nine separate buildings constitute the Shanghai Museum of Glass, which forms the museum park. 


\section{Duan Wu, Chenxi Yao, Jiping Wang}

Facilitating innovation in the economy of choice: A case study of research on museum

By comparing the future development trend of the museum: participatory museum, community-based museum, and Shared museum, we found that the Shanghai Museum of Glass is not good enough on community-based and shared, so we redesigned the museum's Activity-system map (Figure 17) and find some innovation activities (orange blocks):

- Artists community

- Temporary exhibitions

- Lectures and speeches

- Library for all people

- Participatory explanation system platform

- On-line Museum

\section{Mapping Activity Systems of Shanghai Museum of Glass after design}

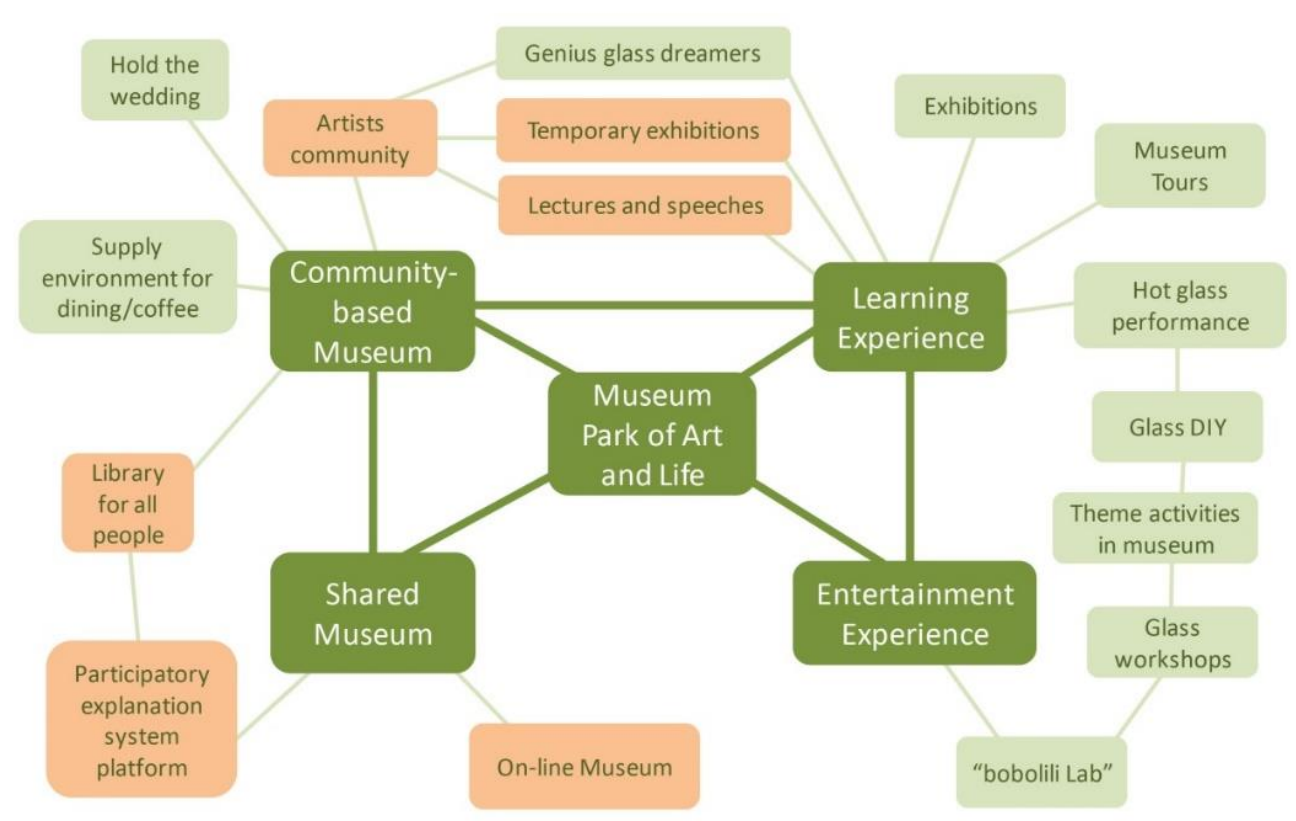

Figure 17: Mapping Activity system of Shanghai Museum of Glass after design

Through the addition of Artists community, Temporary exhibitions, and Lectures and speeches, the Shanghai Museum of Glass can attract more professional scholars in the art field and artslovers. Artists and visitors will have more communication and interaction with each other which makes art more integrated into people's life.

The establishment of the library and participatory explanation system platform will enable the visitors to have an in-depth understanding of the artistic value of museums and arts. Visitors can share their minds and spread knowledge. The on-line museum allows visitors to visit the museum anytime, anywhere which brings the audience closer to the museum. The new activity-system map provides a reference for the future development of the Shanghai Museum of Glass. The new activities will motivate more visitors to walk into museums, exchange their minds and promote the generation of knowledge. It can improve the influence of the Shanghai Museum of Glass and increase the future competitiveness of it.

\section{Conclusion}

After tried to use the framework on the Glass Museum of Shanghai, we find out the positive comments from the staff and managers of the museum. The activities according to the framework will be carried out in the future and we will keep following the data and feedback. 
In this case, during the innovation process, design played a core role in the whole team and shows the leading innovative strategy in the process. From the feedback of the case, we tried to embed the double diamond design model (original from the British Design Council) into our innovation framework and tries to add more process value into it. (figure 18)

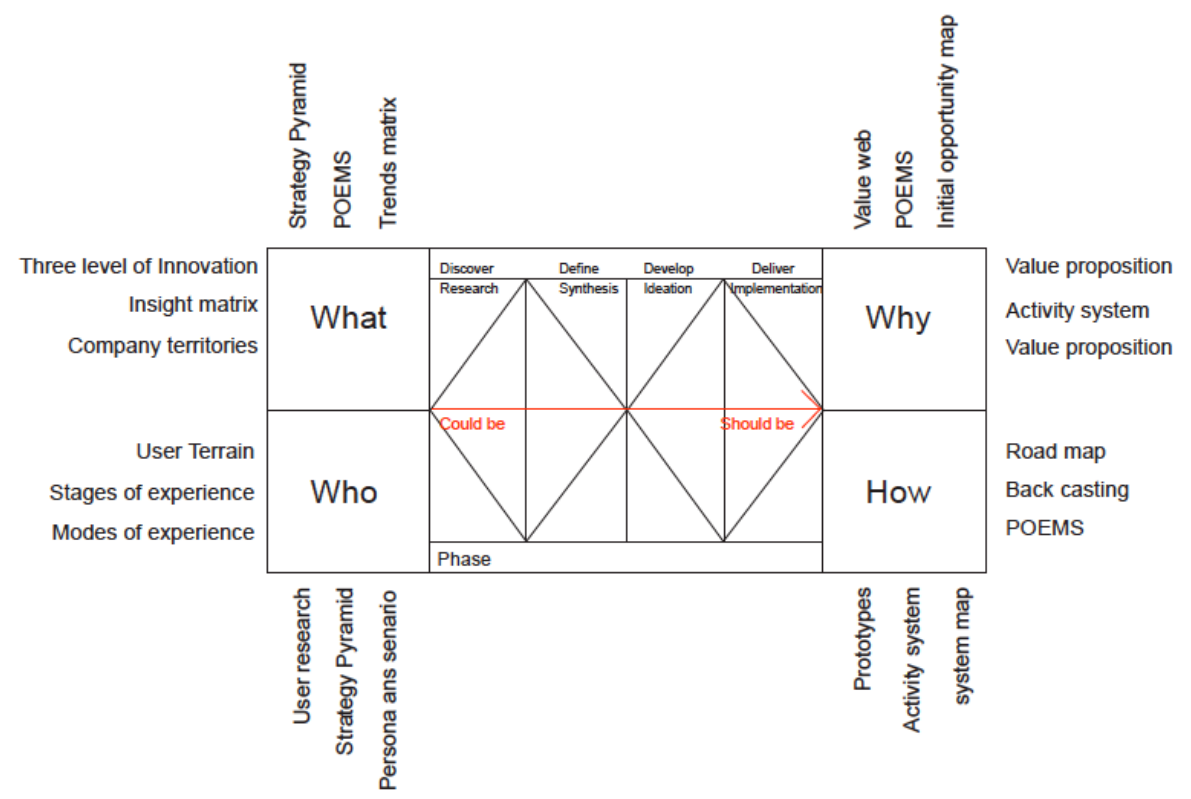

Figure 18: Revised museum innovation model

In the coming future, we will be facing problems in a more complex, scalable and scoped level, and there will no longer be single correct answers to solve them. We need to see beyond symptoms to the underlying challenges, visualize abstract data to discover unexpected patterns, reframe orthodoxies about what is valuable, recognize the aspirations and needs of all stakeholders, and understand the new flexibility in organizations and technologies that change how ideas are realized. Meanwhile, for the innovation model for museums, its value is not at giving the right answer, but to ask the right question or expand the questions that were asked. To take the challenging in the economy of choice will need gaining a complete view of the context and also zoom into different layers. Innovation model provides a sound hypothesis in the uncertain choice of economic, although what might constitute a successful solution is not entirely distinct, it helps to make fast, informal sketches that work descriptively and prescriptively. Combined with the future development trend and innovation model for museums, museums can explore more possibilities of development in the choice of economy to improve their competitiveness.

Innovation is a process that requires specialized interdisciplinary practice that exemplifies the highly collaborative and strategic nature of design thinking. The museum innovation model also bridges ideas and knowledge with different disciplines such as business studies and help to facilitate future collaborations between academics and practitioners. In this process, the designers 'role is also changing to be the leader, the generalist, the user advocate and the analyst. The museum innovation challenge is still in an early stage, and this research will continue with the revise of the innovation model and the application to try and test them.

\section{Acknowledgments}

Shanghai Summit Discipline in Design supports this research and the Fundamental Research Funds for the Central Universities. The authors especially thank the Editors of the Journal for the many valuable comments on the previous version of the paper which has improved its quality and content to the present state. 


\section{Duan Wu, Chenxi Yao, Jiping Wang}

Facilitating innovation in the economy of choice: A case study of research on museum

\section{References}

- Alshammari, A. A., Rasli, A., Alnajem, M., \& Arshad, A. S. (2014). An exploratory study on the relationship between organizational innovation and performance of non-profit organizations in Saudi Arabia is. Procedia - Social and Behavioral Sciences, 129, 250-256. Crossref

- Art Institute of Chicago official website: http://www.artic.edu/visit/accessibilit

- Eid, Haitham Abdelrazek. (2016) The museum innovation framework: a museum perspective on open innovation, social enterprise, and social innovation. Diss. School of Museum Studies.

- Hudson, K. (2014). The museum refuses to stand still. Museum International, 66(1-4), 136143. Crossref

- Kotler, Kotler, N. G. /., Kotler, P. /., \& Wendy, I. (2008). Museum marketing and strategy.

- Lin Li. (2015). Museum reform and reflection in the era of experience economy--The American History Museum Connor Perry innovative business framework as a case. Southeastern culture, (04),107-112.

- Liuhe Zheng,\& Peng Liu. (2013) Art Museum ecosystem: a new replacement mode. [J]. Cultural and artistic exploration, 6(02), 152-164.

- Porter, M. E. (1996). What is strategy? Harvard business review. Harvard Business Review, 86(5), 926-929.

- Shanghai Museum of Glass official website: http://www.shmog.org/

- Whitney, P. (2015). Design and the economy of choice. She Ji the Journal of Design Economics \& Innovation, 1(1), 58-80. Crossref

- Wikipedia: https://en.wikipedia.org/wiki/Art_Institute_of_Chicago

- Yuha Jung. (2011). The art museum ecosystem: a new alternative framework. Museum Management \& Curatorship, 26(4), 321-338. Crossref

- Zhihu web: https://zhuanlan.zhihu.com/p/23337356 